\title{
The Verbal Adjectives as Part of Compound Words in the Albanian Language Vocabulary (ALV), 2006
}

\author{
Ma. Evis Hudhëra \\ Universiteti “Ismail Qemali” Vlorë, Departamenti i Gjuhës dhe Letërsisë Shqipe \\ evishudhera@gmail.com
}

\section{Doi:10.5901/jesr.2014.v4n6p83}

\section{Abstract}

\begin{abstract}
Vacabularies are art work, in which can be done a lot of works with different themes and can be donne observations, various scientific studies, form the descriptive ones to the deep scientific ones. In our study we used this marvelous treasure of Albanian language, together with its features and occurences. Vocabularies are not only registrars of the word and phraseology, the lexicology treasure and semantics, but they play an important role in the dominnation of the albanian language and in the expansion of linguistic and communicating competencies. During the last century and the begining of this century, the vocabulary of albanian language has dramatically developed in all its aspects, developments that stand out in two directions: in the continous enrichment and the endurance to the foreing languages with which it is in contact, an endurance that mainly shows signs of alarms of threats.
\end{abstract}

Keywords: Albanian language ,vacabulary, compositions, compounds of the verbal adjectives.

\section{The Aim of the Study}

The extraction of the compositions with secondary compounds of the verbal adjectives from the ALV, 2006, which will serve for the construction of another tinny vocabulary in a different moment, and the interpretation of the lexicology richness of the ALV (2006).

\section{Methods and Materials}

In this study we have done sincronyzing analyses, within the lexicology and structural semantics and we mostly used the method of semic analyses (J. Thomai 2009), by comparing many lexical and semantic units, in order to distinguish the features of these compositions. For the scientific analyses we have used the inductive method, which has brought some interesting results. The dedective methode was also used because of the availability of the theorical treatments, morphologic and structural classification etc,.

\section{Results}

The Albanian Language Dictionary, 2006 in the lexicography of Jani Thomai is the most achievable lexicological work realized in the $21^{\text {st }}$ century. This vocabulary has almost 48 thousand words, 10 thousand more units than the Albanian Vocabulary of Nowadays, 1980. This treasure means that in all the paradigmatic groups there is an increase of the vocabulary units, which have entered the united form of Standard Albanian. The vocabulary of 2006 is a normative one, and according to Prof. Androkli Kostallari (Kostallari A 1972) argues that the normative of a vocabulary means meeting certain criteria as: 1) the selection of the words that are included in the vocabulary glossary; 2) the selection of the linguistic phraseology equal to the word; 3) the decomposition and determination of the word meaning and its ideas; 4) the stylistic notes that determine the area and the boundaries of a certain word; 5) the description of the definitions with rich illustrating material; 6) the grammar notes based on norms and basic foundation of the evolution; 7) the determination of the rules of writing and 8) putting the accent according to the pronunciation rules.

Very important parts in this vocabulary constitute the compound words or compositions. Composition is the word forming way which is more productive, and it creates new words composed by two or three motivating themes. According to Prof. Kostaq Cipo (Cipo K 1972) compositions are occasional, laconic expressions, spurts and casual use of words. This means that the compositions come from different lexical-grammar parts in the Albanian language. We have studied 
the compound words that have in their composition as a second part a verbal adjective like gjakftohtë (coldblooded), gojëmbërthyer (grasped mouth), ëndërrvrarë (dream ruined), fjalëmprehtë (sharp mouth) etc.

The compound adjectives are formed by joining two related themes and ending up in a new notion, so giving a new lexical unit. There are a lot of such adjectives in the ALV (2006) like: acidurues (acidbarer), armëlarë (gunwashed), arsimdashës (education lover), ballëvrenjtur (sullen face), barkthatë (hungry tummy), barngrënës (grass eater), fjalëkursyer (word saver), faqepalarë (dirtycheecks), gjuhëzënë (tong tied), hundërrjepur (nose peeled) etc. The new words in general are divided by their way of forming and construction. The compositions are formed in the process of word formation based on existing models of our language and that are born and developed historically, and based on syntactic relation of lexical categories or other possibilities of such a relation. So the composition is a particular type of word syntactic-morphologic word formation (A. Kostallari, Studime mbi leksikun dhe mbi formimin e fjalëve në gjuhën shqipe I, 85-86, 1972). The words of the adjective composition found in the ALV (2006) have two kinds of relation between them:

1) Conjunctive: the compound themes have equal functions. These are indefinite adjectives but no verbal adjectives.

2) Subordinate: one of the themes determines the other, so the notion of the adjective is larger than the adjective itself. One of the parts is defined and the other is defining. All the compounds that we found are defining. In ALV (2006) we find many adjective compounds where the second part is a verbal adjective. In the word forming themes the first one is always a noun.

Prof A. Kostallari (1972) states that: 'the verb theme itself (and not the ones that come form the verbs) do not enter in Albanian language as first components in none of the productive types of the compounds" so we have paid attention to the second word forming theme which always comes from a verb.

According to the word forming themes that participate in these adjective forming we divide them in three groups: a) adjectives composed by noun+ participle adjective like gjakshuar, (gjak + i shuar) [blood + blasted] , flokëzbardhur (flokë + i zbardhur) [white haired], hundërrjepur (hundë+ i rrjepur) [nose +peeled], gojëmbyllur (gojë + e mbyllur) [closed+mouth], cipëplasur (cipë + e plasur) [shame +burst], buzëdjegur (buzë + e djegur) [lip + burned] etc. Here we are going to notice the subtypes based on the word formation or form formation suffix. b) noun + verbal adjective like gjaknxehtë (gjak + i nxehtë) [hot +blooded], gojëmprehtë ( gojë + e mprehtë) [smart mouth], ballëhapët ( ballë + i hapët) [open face],etc., c) noun+ action noun ending in -ës or -ues, which we have not studied as their second theme is a noun; barngrënës (bar + ngrënës) [grass + eater], bakërmbajtës (bakër + mbajtës) [copper keeper], drungrënës (dru + ngrënës) [wood eater], fletëmbajtës (fletë + mbajtës) [paper keeper] etc.

A) Here are some examples where we notice the way the noun is linked to the participle adjective: ballëhapur (straight forward), ballëndritur (smart head), barkngjitur (tummy tucker), ballëvrenjtur (angry), gjuhëzënë (quiet), gjakpërlyer (bloody covered), gojëtharë (dry mouth), frymëprerë (stunned), fytyrëqeshur (happy face), faqenxirë (ashamed), leshprerë (hir cut), mendjemykur (moldy mind), pallëlarë (washed sword), nofulldalë (prognathous) mustaqepërdredhur (culry mustashe) etc. So this kind of adjectives are formed from two themes where the first is a noun and the second is an adjective formed from the present participle of the verb as: ballë+ $\mathrm{i}$ hapur (open forhead); ballë+i ndritur (brightened forhead); bark+i ngjitur tummy tucked); ballë+ i vrenjtur (angry forhead); gjuhë+e zënë (tied tounge); gjak+i përlyer (bllod covered); gojë+ e tharë (dry mouth); frymë+ e prerë (cut breath); fytyrë+e qeshur (happy face): faqe+e nxirë (blackend face); lesh+ e prerë (hair cut); mendje+e mykur (molded face); pallë+ e larë (washed sword) etc.

The composition formed by two themes where one contains the other Kostaq Cipo (1972) calls them Bahuvrihi. The relation between the noun as the first theme and participle as the second theme are not predictive conections, because when we say empty tummy that does not mean that the tummy is empty, but the person is very hungry. The relation created between the first theme which is the subject and the second theme is not seen within the formed unit, but in relation with other units. Prof. Androkli Kostallari (1972) calls these adjectives exocentric and states that " in general these are quality adjectives which describe a quality in a mediating manner. So this composition means that the second theme defines the first and is its attribute, but the whole adjective notes a feature related to the subject, a human etc out of its context. For example: drawn eyed does not mean that the eyes are drawn, but the person has drawn eyes, cold blooded does not mean that the blood is cold, but the person is cold blooded, molded mind does not mean that the mind is molded, but the person is, knee-cut does not mean that the knees are cut, but the person has weak knees, open hearted does not mean that the heart is open, but the person has an open heart, tight handed, not the hand is tight but the person is a money pincher, hot headed, not the head is hot, but the person is very angry, etc.

Most of these kinds of adjectives are presented in the ALV as: 1) nouns and adjectives orëfjétur (sleep hour) adj., and no., someone whose things do not go right, unfortunate: a person whose hour is sleeping, orëfjetur.; orëharrúar 
(unlucky) adj.,and noun., the luck has forgotten the person, unlucky.; Gjakshuar (bloodblasted), gjuhëtharë (dried tounge), gjunjëprërë (knee cut), gojëprishur (bad mouth), dorëmbledhur (penny pincher), duartharë (lazy hands), dhëmbëdalë (outing teeth), cullufedredhur (curly haired), cipëngrënë (shameful), ditëprerë (date cut), catiprishur (roof broken), fjalëthyer (word broken), faqembushur ( cheecky face ) etc., 2) as nound and adverbs fytyrëvrénjtur adj (angry face). 1. Angry in the face; objective. Happy faced. 2. as an adverb. With an angry face: stayed angry faced; gojëhápur adverb (openmouthed). 1. With an open mouth: slept openmouthed. 2. as an adjective, fig. a condition when we are so surprised or astonished: left us open mouthed. 3. fig. without patience: waited openmouthed; gojëmbýllur adj. (closed mouthed), as an adverb, speaks too little / keeps a secret; quiet; hundëvárur adj. (sullen face), as an adv., angry and hurt etc. 3) only as adjectives fytyre qeshur (happy face), gushëlëshuar, (fallen neck), gojëmbajtur (mouth keeper), dorëzgjidhur (untied handed), buzëpjekur (suffering lips) , etc..

In this type of word formation we will include adjectives that are formed by a noun +(negative particle Patparticiple), so the second part is the type non washed, non smiled, non gone, non let, non rocked, as antonym adjectives; washed face-nonwashed face, smily mouth-non smily mouth, etc. The adjective djeppapërkúndur adj., (the non rocked crib) and as a curse childless cribbed; djeppatúndur adj., (the non rocked crib) and curse., childless cribbed etc. Their presentation in the vocabulary has a different part and they do not behave as antonym pairs. The adjectives with the second part a participle are very productive in albanian language, because this part has conection with the verm meaning, which is their root theme.

B) the adjectives composed by a noun+ verbal adjective with -të suffix. This suffix is productive in Albanian language with verbal themes of the simple present tense the first person singular. This suffix forms adjectives with quality features when used in pre thought meanings as childless cribbed, hot blooded, cold blooded, dry throated, smart

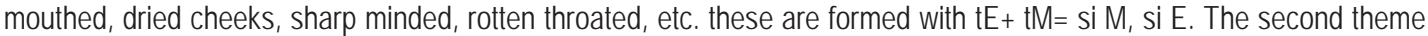
comes form a verb as sharp<sharpened, cold<cold, heat<heated, dry< dried, rot<rotten, which behave as synonyms with the participle adjective in these compounds. Blood +hot, blood + cold, throat+ dry, mouth +smart, throat + rot, etc. these adjectives are of the same type. This type of word forming is also very productive in Albanian language because we have a cold blooded person (who has cold blood), smart mouthed (has a smart mouth), rotten throat (has a rotten throat) etc. in these cases they are only adjectives where the first noun theme defines the second verbal theme.

Prof Jani Thomai (2011) studies the phrasal units which form words by stating that there are no significant changes in the understanding manner during the process of composing, because these units set total synonymous relations. These are productive adjectives as we see the adjective features that relate to the verb meaning of which it has derived. If for the verbal adjective the theme is the verb, for the compound adjective the forming theme is the whole composition as hot-blooded, hot-bloodiness, and the adjective has also importance, because there are other compound formed as throat dried, tree dried, tummy dried, hand dried presented in the ALV (2006).

c) the compound adjectives formed by noun+ action noun by adding the suffixes -ës and -ues. This suffix is very productive as it creates adjectives that show the relation of the object with the action of the verb, therefore showing the feature of the actor as dëmsjéllës,-e adj., and noun.,(damage bringer) dëmprurës.; gjakndalës (blood stopper) (acid endurer), acidurues, hekurmbajtës (iron holder), dritëpeshues (light weighter), dhembjeqetësues (pain killer), bishtlëkundës (tail wrangler), besëshkelës (faith breaker), bimëngrënës (plant eater), dhembjeprurës (pain causer), mëndafshpunues (silk worker), mikrobmbartës (microbe carrier), llogaridhënës (account giver) etc that are formed by blood+ stopper; acid+ bearer; iron+ holder; light+ weighter; pain+ causer; silk+ worker; microbe+ carrier; account+ giver etc. Here we notice that the acting noun which is a second theme acts on the first theme, so when we say pain causer medicament (causes pain) or acid endure (endures the acid), plan eater (eats plants) (V. Memisha 1999). Even these kinds of adjectives occupy a considerable place in the Albanian Language Dictionary 2006. Their particular feature is that these adjectives are binary as well as the quality of actors like nouns. This type of compound is included in the conversion of adjectives in nouns and we can call them adjective -nouns. For example watchmaker, teachers, lawyers, etc.. We will not study this class because the semantic developments are not noun + adjective but noun + noun. We can say that these kinds of adjectives are quite productive in Albanian language.

d) compound adjectives formed with the second theme a verbal adjective with the suffix - or as; orally presented, prepared, extramural, etc.. The suffix -or forms adjectives with defined meaning, where it is clearly understood that the relationship characterized to another item to or relation to the action expressed by the verb. These kinds of adjectives formed with composition are not numerous in Albanian Language Dictionary 2006. We can only count three. So it is clear that these kinds of adjectives can be less productive. We have found a few adjectives of the type noun + verbal adjective with -shëm suffix. Dritëpërshkueshëm, (light permeable) dorëpërdórsh/ëm (i), -me (e) mb. i tanipërtanishëm (now used); i sotpërsotshëm (recent). It is formed by (light+ permeable) dritë + i përshkueshëm where the adjective permeable 
defined the noun light. The adjective is formed by the participle permeable with the meaning easy to go through (V. Memisha 1999).

\section{Conclusions}

The Albanian vocabulary not only is very rich in compound word formations but also is very easy to use for different categories of population. All Albanian people of all level of education can search the vocabulary and find what they need. In the vocabulary we have found plenty of examples from the three discourses of Albanian language and we have brought out some examples of each: the simple pronounciation, conversational discourse and book discourse (or raised).

a) The simple pronounciation; torned ass, scrapped ass, open legged etc.

b) conversational discourse; adj brinjëdálë (bonny ribs), very frail, flokëpalarë (dirty hair), brezvënë adj. (belt put), as a noun. Or verb., dismal, unlucky (for women).

c) book discourse; ballëndrítur adj. poetry., Fig. clear conscience: bukurtingëllúes,-e adj-.. speaking that creates beautiful sound. Ilërëpërvéshur adj. 1. Has rolled up sleeves. 2. As adverb. figuratively. with momentum and unsparingly: working with fury, etc..

\section{References}

J. Thomai, Prejardhja kuptimore në gjuhën shqipe, Tiranë, 2009, 54.

Leksikologjia e gjuhës shqipe, 2011, page 150.

Studime mbi leksikun dhe formimin e fjalëve në gjuhën shqipe I, 1972, page 64.

Studime mbi leksikun dhe formimin e fjalëve në gjuhën shqipe I,1972, page 95.

Studime mbi leksikun dhe mbi formimin e fjäleve në gjuhën shqipe II, 1972 page 14.

Studime mbi leksikun dhe mbi formimin e fjalëve në gjuhën shqipe I, 14, 1972.

Studime mbi leksikun dhe mbi formimin e fjalëve në gjuhën shqipe I,1972, page 87.

V. Memisha, Dukuri semantike gjatë formimit të mbiemrave prejpjesorë në gjuhën shqipe, Gjirokastër, 1999, page 65

V. Memisha, Dukuri semantike gjatë formimit të mbiemrave prejpjesorë në gjuhën shqipe, Gjirokastër, 1999, page 78. 